\title{
CRYPTOCOCCOSIS: A REVIEW OF THE BRAZILIAN EXPERIENCE FOR THE DISEASE
}

\author{
Mara C.S.M. PAPPALARDO(1) \& Márcia S.C. MELHEM(2)
}

\begin{abstract}
SUMMARY
Cryptococcosis is a systemic mycosis caused by Cryptococcus neoformans. The disease occurs in patients with cellular immunodeficiency. The incidence of cryptococcosis arises with AIDS, and mycosis is one of the opportunistic infections that defines AIDS. After the HAART era the occurrence of cryptococcosis decreased all over the world, but it still continues to be a prevalent disease in Brazil. Thus, we consider this paper to be very important as a result of our reviewing of Brazilian literature regarding some relevant aspects of that disease.
\end{abstract}

KEYWORDS: Cryptococcus neoformans; Cryptococcosis; AIDS; HAART, Brazilian literature.

\section{INTRODUCTION}

Since the discovery of Cryptococcus by Sanfelice, 108 years has passed by, and we know much about this capsulated yeast, but there are many areas to be researched that evolve the interaction of the agent with human host. Some aspects of this binomial are fascinating, but not exactly clear. Some of these aspects of the history of disease, extremely modified by acquired immunodeficiency syndrome (AIDS) and more recently by highly active antiretroviral treatment (HAART). Other aspects are related to the biology of the etiologic agent. The knowledge gained by the studies of molecular biology and of antifungal sensitivity as well biochemical studies about Cryptococcus neoformans virulence have contributed in elucidating several points about that yeast. Studies had became more intensive since the 80's due to the epidemic AIDS and cryptococcosis has became an important opportunistic infection due to both by increasing the morbidity rates and mortality rates ${ }^{39,64}$.

Brazilian literature about cryptococcosis contributes significantly due to the elucidation of related facts regarding the agent and the disease. The aim of this study is to review the Brazilian literature, including many unpublished theses that have new findings of great importance and deserve being highlighted in reviews about cryptococcosis.

In Brazil, the honorable professor Dr. Carlos da Silva Lacaz and his master, Dr. Floriano de Almeida, first reported cryptococcosis, here describing the two first reports in 1941 and 1944 respectively, according to REIS-FILHO et $a l^{73}$.

Ecological and Epidemiological Aspects: Cryptococcosis is a worldwide disease and its occurrence prior to the AIDS epidemic was sporadic and generally associated to low cellular immunity. Currently, cryptococcosis occurs in the general population in a relatively low incidence taking in account the wide distribution of $C$. neoformans in the environment that makes it possible to foresee a high probability of spore inhalation ${ }^{5}$. Occurrence of subclinical, asymptomatic forms of the disease is unknown and studies, such as cellular immunity surveys using intradermic tests with the yeast antigen in patients without clinical disease are rare, and therefore the extent of the subclinical form has not been properly evaluated ${ }^{41,48}$. C. neoformans' habitat in the environment is on the ground, in decomposed vegetables, bird and bat feces which are found both in urban and rural areas of Brazil $3^{3,5,7,27,47,50,55,58,59,66,67,75,89,90}$. Studies of LAZERA et al. ${ }^{43,44,45,46}$ gave new dimensions to the ecology of the cryptococcosis agent in Brazil demonstrating that yeast is associated not only to Eucalyptus $s p$ gender, but also to other species of trees. The most appropriate methodology for $C$. neoformans isolation from environment samples was well evaluated by MONTENEGRO \& PAULA $^{55}$ and BARONI ${ }^{5}$ who successfully isolated two species of the yeast in São Paulo and Rio de Janeiro, Brazil.

Infectious particles spread by air represent the most important source of pulmonary contamination after inhalation, and there is no consensus about its origin: whether or not it is sexual (basidiospores) or asexual (conidia $^{39}$. Molecular studies with Brazilian samples showed that the majority of infections are caused by heterothallic strains classified as $\alpha$ phenotypes (mating-type MAT $\alpha$ ) that are also prevalent in environmental samples of C. neoformans ${ }^{6}$.

C. neoformans has five serotypes: A, B, C, D and AD of two varieties called neoformans (A, D and AD) and gattii (B and C). FRANZOT et al. ${ }^{30}$ proposed the reclassification of A-serotype into a new species: grubii. Several epidemiological inquiries show the heterogeneous distribution of these subtypes of cryptococcosis agents in several countries, verifying, 
consequently, the hypothesis of a correlation between etiologic agent variety and geographic regions according to MELO et al. ${ }^{49}$. In Brazil, the pioneer study of LACAZ \& RODRIGUES ${ }^{40}$ showed that the majority (64\%) of 25 biological samples belonged to the neoformans variety with the A-serotype prevailing followed by B and D. Predominance of this serotype into our clinical setting was therefore, confirmed by other authors both with biological and environmental samples ${ }^{10,11,12,32,52,53}$. The possibility of transformation between $\mathrm{A}$ and $\mathrm{AD}$-serotypes was reported by BARRETO DE OLIVEIRA ${ }^{6}$ and REZENDE ${ }^{74}$. The gattii species are endemic in the northeast of Brazil, which is responsible for $71 \%$ of cases $^{18}$.

Molecular studies about etiological agents contribute to the comprehension of the Brazilian cryptococcosis epidemiology. An Iberian American study done with strains from nine countries including Brazil showed low genetic variability in 340 strains of $C$. neoformans being 56 clinical and 9 environmental samples. The methodology used was PCR (Polymerase Chain Reaction) associated to RFLP (Restriction Fragment Length Polymorphism) and it revealed only three molecular types of species of Brazilian strains among the eight types of species identified in the study ${ }^{52}$. FRANZOT et al. ${ }^{29}$ suggested a clonal origin of strains acquired in Brazilian cases explain the low genetic diversity observed among the 51 samples collected from the cities of Belo Horizonte and Rio de Janeiro by way of PFGE (Pulsed Field Gel Electrophoresis) and RFLP studies, and they have pointed to important differences from North American strains. ALFP (Amplified Fragment Length Polymorphism) methodology applied by BOEKHOUT et $a l .{ }^{8}$ has confirmed hybridism of $C$. neoformans. VIVALDINI ${ }^{97}$ has verified by RAPD (Randomly Amplified Polymorphic DNA) analysis great homogeneity among 89 clinical samples from the São Jose do Rio Preto region, in accordance with a strong similarity of genotypes previously described by ALMEIDA ${ }^{2}$. IGREJA ${ }^{33}$ has verified very similar profiles evaluating 60 strains in Rio de Janeiro city. HORTA et $a l .{ }^{32}$ have applied RAPD technique in 17 clinical samples and 10 environmental samples from Rio Grande do Sul state, and they have verified great differences in molecular profiles. REZENDE ${ }^{74}$, using the same methodology but with other primers also verified genetic heterogeneity without dominance of any molecular type species among clinical samples collected in the cities of Araraquara and Ribeirão Preto, suggesting the absence of a correlation among sources of infection. DNA profile studies made it possible for REZENDE ${ }^{74}$ and IGREJA ${ }^{33}$ to demonstrate the maintenance of the same agent through all the disease's course even with antifungal therapy in some cases. In one patient, IGREJA found mixed infection with the two species, gattii and neoformans ${ }^{33}$.

Generally, C. neoformans var. gattii infects immunocompetent individuals, such as primary or secondary diseases, in contrast to var. neoformans, which has a strong association between the variety and the immune host status ${ }^{36,85}$. In Brazil, as occurs in other countries, cryptococcosis rates by gattii species in patients with AIDS are lower than the population, with other underlying diseases, or even without immunodepression, a data consistent with the worldwide literature ${ }^{6,13,26,74,77,78,79,83,97}$. PAULA et al. ${ }^{69}$ in a study of the cryptococcosis agent, in 40 cases not associated to infection by HIV, demonstrated the proportion of gattii of about $33 \%$ while in AIDS patients this rate is below $1 \%{ }^{51,58,62}$. CORREA et al. ${ }^{22}$ have observed alterations, through tomographical images, in 11 immunocompetent children with infection of the central nervous system (CNS) by gattii variety. In a study carried out in Rio de Janeiro City, patients with AIDS exposed to spores of
C. neoformans species in a home environment have presented a risk to cryptococcosis two times more than non-exposed AIDS patients ${ }^{66}$.

NISHIKAWA et al. ${ }^{58}$ published the most complete study to the present, in which they proposed that the prevalence of neoformans species is not homogeneous all over Brazil considering 467 environmental and biological samples. The authors verified the prevalence of B-serotype as the etiologic agent of non- AIDS patients in the northeast of Brazil. Moreover, interesting data reveal the occurrence of C-serotype in negative $\mathrm{HIV}$ patients and high rates of $\mathrm{AD}$-serotypes $(1.3 \%)$ in relation to $\mathrm{D}$ serotypes $(0.4 \%)$ in the total samples.

Clinical and laboratorial aspects: The influence of agent variety in disease prognosis was well studied by SEVERO $^{86}$ that concluded a positive correlation between disease caused by neoformans species and death. The predisposed disease was AIDS (48\%) or other diseases associated to cellular deficiency (33\%) in cases with neoformans species. This and other aspects of agent and cryptococcosis diseases can be appreciated in the excellent review published by the author ${ }^{87}$.

The yeast has a strong tropism to CNS but it can occur in localized forms or the disseminated disease associated, or not to aids ${ }^{4,9,15,18,25,42,84,92,95}$. Systemic forms of the disease are diverse and ZANINI et al. ${ }^{98}$ observed ulcer as the first sign. Virulence of the agent invading different organs and its participation in death can be verified in Brazilian studies using histopathology analysis ${ }^{28,53,71}$. Meningoencephalitis is the most common form of cryptococcosis infection. About $70 \%$ to $90 \%$ of patients with AIDS and CNS cryptococcosis have signs and symptoms of sub acute meningitis or meningoencephalitis as follows: headache, fever, lethargy, coma, personality disorder and loss of memory which occurs 2-4 weeks previous to diagnosis ${ }^{35}$. PAPPALARDO ${ }^{65}$ showed that in 35 patients the following most common signs and symptoms of cryptococcosis were apparent at the time of diagnosis: cephalea (97.1\%), nausea and/or vomiting $(51.4 \%)$, fever $(34.3 \%)$, visual disturbance $(20 \%)$, altered mental status (11.4\%), seizure (8.6\%) and menigeal signs $(5.7 \%)$. The same findings had been described but in different proportions by other authors $^{31,99}$. Cephalea is the second cause of pain in AIDS patients, and CNS cryptococcosis is responsible for $40 \%$ of this symptom ${ }^{1}$.

The disease is more frequent in adults, but despite being rare it can affect children. CORREA et al. ${ }^{21}$ considered that in Brazil there is an increase of cryptococcosis rates in the childhood population considering the incidence of $24.4 \%$ observed in the group of patients studied. DARZÉ et al..$^{24}$ reported a similar incidence of about $30 \%$ of 104 cases occurring in the population of less than 15 years old. Cryptococcosis can be associated to other mycoses especially oral candidiasis, dermatophytosis, pityriasis versicolor and also to systemic mycoses, such as paracoccidiodomycosis or histoplasmosis according to three cases of AIDS reported by CAIUBY et al. ${ }^{10}$.

Laboratory diagnosis of CNS cryptococcosis can be done by cerebral spinal fluid (CFS) examinations or by histopathological assay or even by the polysaccharide capsular antigen test. Several Brazilian authors have related chemocytologic aspects of CFS on cryptococcosis associated or not to AIDS, but a specific pattern of the disease does not exist $\mathrm{t}^{24,35,72,73,92,93}$. The capsule, a morphologic aspect that distinguishes the genre Cryptococcus sp is considered an important factor of yeast virulence ${ }^{38}$; however, there are cases described of the disease caused by 
a non-capsulated agent or by low capsule production ${ }^{17,37,82}$. Other virulence factors such as phenol oxidase production were studied in clinical strains by REZENDE ${ }^{74}$. PAULA et al. $^{70}$ proposed a sensitive and economic procedure to evaluate the production capacity of that enzyme. Phospholipases and proteinases are virulence related enzymes, and SILVA ${ }^{88}$ found production rates of $84 \%$ and $20 \%$ respectively in isolated samples from pigeon excrement. In two other papers, REZENDE $^{75}$ using samples from pigeon excrement and VIDOTTO et $a l .{ }^{96}$ using clinical strains, verified high production of phospholipase in Brazilian strains suggesting that there is strong virulence.

As highlighted in the Brazilian literature, the best option for disease diagnosis in terms of high sensitivity and quick results is the detection of polysaccharide antigen by latex particle agglutination, in body fluids such as: CSF, serum and urine. The disadvantage of this is that it is an imported product and has a high $\cos ^{12}$. The most economical and practical diagnosis of CNS cryptococcosis is done by direct examination of CSF sediment prepared with India ink which has a sensitivity of $96.3 \%$ in AIDS cases ${ }^{13,73,77,94}$. The yeast count does not correlate with the antigen titers but can indicate severity of disease $\mathrm{e}^{12,65}$. The direct examination and the culture can have discordant results ${ }^{12}$. Since no diagnostic method has total sensitivity and specificity, a combination of several methods is recommended. Culture and isolation of the agents is the gold standard method having greater specificity and almost $100 \%$ sensitivity for cryptococcosis diagnosis ${ }^{12,80}$. However, OLIVEIRA et al. ${ }^{63}$ in studies of 66 cases of CNS cryptococcosis showed insufficient use of culture method as a diagnostic means, and they emphasized that sensitivity could vary according to each laboratory. Isolation for gender and species identification and confirmation of etiologic agent is done on agar for analysis of morphologic and chemical features of yeast. Histological analysis can be done with several dyes, the most commonly used being hematoxylin-eosin dye and Gomori dye. Fontana-Masson dye is useful in the identification of capsule-deficient yeast ${ }^{38,39}$.

Therapeutic aspects and antifungal sensitivity testing: Antifungals used in cryptococcosis treatment are amphotericin $\mathrm{B}(\mathrm{AB}), 5$-flucytosine (5-FC) and fluconazole (FZ) $)^{87}$. PASSOS et al. ${ }^{68}$ have studied "in vitro" the antifungal activity of a plant extract against the yeast. Meningeal cryptococcosis-associated AIDS treatment is done in two phases: the first one in the acute or induction phase, for six to 10 weeks or until CFS becomes sterile. The second one is called the maintenance phase for an indefinite period. Generally, authors consider two consecutive negative results as criteria for determining the change from the induction phase to the maintenance phase ${ }^{80}$. Usually AIDS patients are treated at the initial phase with $\mathrm{AB}$, with or without 5 -FC, but relapses are very common in $50 \%$ to $75 \%$ if the therapy is discontinued ${ }^{80,81}$. CAMPOS et al. ${ }^{16}$ revealed minor adverse effects, minor relapses and late death in cases receiving $\mathrm{AB}$ therapy associated to 5-FC. Current tendency is the use of high doses of $\mathrm{AB}, 0.7 \mathrm{mg} / \mathrm{kg} / \mathrm{day}$ to $1 \mathrm{mg} / \mathrm{kg} /$ day during the first two weeks of treatment associated to minor doses of $5-\mathrm{FC}, 100 \mathrm{mg} / \mathrm{kg} / \mathrm{day}$, followed by high doses of FZ, $800 \mathrm{mg} /$ day for eight to 12 weeks. In the maintenance phase $200 \mathrm{mg}$ of FZ are administered, and with this regimen, the cryptococcosis meningitis mortality in AIDS was decreased from $14-25 \%$ to $6 \%$, according a classical North American study ${ }^{80}$.

The Department of Health in Brazil centralizes epidemiological data about cryptococcosis as an opportunistic disease in the National Program of Sexually Transmitted Diseases and AIDS. From 1980 to 2002 (April),
215,810 AIDS cases were registered with $6 \%$ of patients having cryptococcosis at the time of diagnosis ${ }^{54}$. Cryptococcosis can be the first opportunistic infection in AIDS, ranging from $23 \%$ to $48.6 \%$ according to each study done ${ }^{12,65}$. The AIDS Bulletin entitled "Boletim AIDS - Cor $e$ Raça" which was published by the Reference and Training Center of Sexual Transmitted Diseases and AIDS (Centro de Referência e Treinamento em DST/AIDS) of the São Paulo State Health Secretary showed that cryptococcosis rate associated to AIDS has been on the average about $3.7 \%$ in the last 14 years (www.cvs.gov.sp.br). Data from the Epidemiology Division at the Instituto de Infectologia Emílio Ribas a specialized hospital in Infectious Diseases in São Paulo, Brazil, show that CNS cryptococcosis in AIDS patients both in inpatients and outpatients have generally decreased in the last few years: $7.7 \%$ in 1995 ; $7.4 \%$ in $1996 ; 8.2 \%$ in $1997 ; 6.8 \%$ in $1998 ; 5.8 \%$ in $1999,4.6 \%$ in $2000,3.1 \%$ in 2001, remaining unchanged up to April, 2002. At this hospital, the induction phase of cryptococcosis treatment associated to AIDS follows a guideline of a single therapy with $\mathrm{AB}$, usually with a maximum daily dose of $50 \mathrm{mg}$ since, unfortunately the 5-FC drug was unavailable on the Brazilian market for a while. Mortality ascribed to cryptococcosis in 35 AIDS patients at Emilio Ribas Infectious Disease Institute was $79 \%{ }^{65}$. General mortality in cryptococcosis patients, with or without underlying disease, is around $45 \%-65 \%$, according to Brazilian studies ${ }^{12,28,31,35,60,61}$. A study of 17 cases of CNS cryptococcosis showed that clinical aspects, follow-ups and necroscopy findings were influenced by the presence and the kind of immunodeficiency, that is, a worst prognosis being seen in patients with pre-existing primary disease, such as, diabetes or neoplasia, in comparison to immunodepressed cases under renal transplant therapy or immunocompetent patients ${ }^{28}$.

The most important predictive factor of early death is the patient mental status at the time of diagnosis, but other factors are also applicable: CSF antigen titer $>1024$, CFS cell count $<20 / \mathrm{mm}^{3}$ and age $<35$ years old $^{80}$. Extraneural cryptococcosis, hypernatremia and high counts of fungal cells are also parameters of poor prognosis ${ }^{80}$. Despite of being important aspects for prognosis, intracranial hypertension (ICH) and extraneural cryptococcosis were underdiagnosed according to a Brazilian retrospective study ${ }^{65}$. Cryptococcemia in AIDS patients was observed in $6.6 \%$ of patients with clinical suspicion or previous history of CNS cryptococcosis $^{91}$. Major rates were verified by CORTES ${ }^{23}$ on analysis of 70 blood cultures of AIDS patients.

Besides factors that definitely contribute to therapeutic failure, there are hypotheses for the existence of resistant phenotypes to therapy. Resistant phenotypes are identified in populations of several etiologic agents by means of sensitivity tests that can be done by several methods: dilution in liquid medium, dilution and diffusion on agar medium. Comparisons of test results obtained with agar and in liquid medium were done worldwide as well as in Brazil, confirming the test validity $^{14,19,20}$. The minimum inhibitory concentration (MIC) of the drug against the etiologic agent is the most-used parameter for detecting resistant strains. Since the 80's, North American and European groups were implicated in developing a reference method, the most important being respectively, the NCCLS (National Committee for Clinical Laboratory Standards) and the EUCAST (European Committee on Antimicrobial Susceptibility Testing) subcommittees ${ }^{56,76}$. The current method accepted as reference for the "in vitro" antifungal susceptibility testing is the M27-A2 document from NCCLS ${ }^{56}$. The proposed EUCAST methodology has its guidelines based on NCCLS ${ }^{76}$. However, the M27-A2 
document has limitations in non-fermentative yeasts studies of glucose, such as Cryptococcus sp, and therefore there are studies done by Brazilian authors seeking adequate alternative test conditions for work with this genera against natural or synthetic drugs ${ }^{2,57,65,74,97}$.

In several studies, the majority of $C$. neoformans human samples are "in-vitro" sensitive to FZ and itraconazole (IZ); on the other hand, up to $50 \%$ of the strains are resistant to $5-\mathrm{FC}^{11,33,35,65,74}$. However, VIVALDINI $^{97}$ found clinical strains with less sensitivity to IZ, a fact which was previously reported by ALMEIDA ${ }^{2}$. In another study REZENDE $^{74}$ reported around $18 \%$ of samples being less sensitive to FZ in accordance with data from PAPPALARDO ${ }^{65}$ who found a resistance of $12 \%$ in 168 samples collected from 35 patients.

In C. neoformans environmental samples, about $25 \%$ presented low sensitivity to $\mathrm{FZ}$ while $\mathrm{AB}$ and $\mathrm{IZ}$ were the most effective antifungals ${ }^{5,55}$. The difference of the "in-vitro" response to 5-FC between the two agent varieties was noted by MONTENEGRO \& PAULA ${ }^{55}$. The E-test method was used by SILVA ${ }^{88}$ for analysis of 62 isolated strains of pigeon feces, which were highly sensitive to $\mathrm{AB}, \mathrm{IZ}$ and ketoconazole (KZ) and resistant to FZ for the most part. ALVES \& CURY ${ }^{3}$ observed less sensitivity to $\mathrm{FZ}$ in clinical samples than in environmental samples and to $\mathrm{AB}, \mathrm{IZ}$ and $\mathrm{KZ}$, the authors verifying high sensitivity of strains independent of their origin.

Generally, C. neoformans strains, like the majority of yeasts, are "in-vitro" sensitive to $\mathrm{AB}^{13,33,34,65,74}$. However, there are still serious limitations concerning the credibility of results of testing this drug even when using recommended methods ${ }^{74}$. Because of this and other problems, the test results cannot be used in routine medical practice ${ }^{65}$. It is important to highlight that there is no reference method for the carrying out of susceptibility tests for the cryptococcosis agent and also there is a scarcity of worldwide studies in the literature that correlate clinical prognosis to yeast-sensitivity profile ${ }^{65}$. Therefore, there is inconsistency in the correlation of therapy failure with the presence of "in-vitro" resistant $C$. neoformans strains.

\section{CONCLUSIONS}

Existing data at this precise moment suggests that the main cause for therapy failure in CNS cryptococcosis associated with AIDS is due to the low immunity of the host. Moreover, little is known about the antifungal pharmacokinetics in the CNS of the host in the presence of $\mathrm{ICH}$, or of the role of antifungal cell exo-enzymes, or the virulence of the strain, or even of the genetic or physiologic mechanisms implicated in the resistance of the etiologic agent. Even less is known about the role of each one of these factors in the follow-up of cryptococcosis. The research fields are numerous, and, given the stable morbidity and lethality rates associated with AIDS in Brazil, despite the existence of HAART and other advanced therapies, Brazilian researchers should contribute in clarifying predictor variables of clinical improvement of cryptococosis.

\section{RESUMO}

\section{Criptococose: revisão sobre a experiência brasileira sobre a doença}

Criptococose é micose sistêmica causada por Cryptococcus neoformans. A doença ocorre em pacientes com deficiência da imunidade celular. Com o aparecimento da doença AIDS, a incidência de criptococose aumentou, e a micose é uma das infecções oportunistas que definem um caso de AIDS. Após a era HAART, criptococose parece estar diminuindo no mundo todo, mas continua sendo uma doença prevalente no Brasil. Este artigo visa a análise da contribuição dos autores brasileiros sobre vários aspectos da doença.

\section{REFERENCES}

1. AIRES, E.M. - Dor em pacientes HIV-positivos hospitalizados: aspectos clínicos e terapêuticos. São Paulo, 2002. (Dissertação de Mestrado - Coordenação dos Institutos de Pesquisa da Secretaria de Estado da Saúde de São Paulo).

2. ALMEIDA, A.M.F. - Análise do cariótipo eletroforético de diferentes amostras de Cryptococcus neoformans e correlação com suscetibilidade a drogas antifúngicas. Araraquara, 2000. (Dissertação de Mestrado - Instituto de Química da Universidade Estadual de São Paulo).

3. ALVES, S.H. \& CURY, A.E. - Estudo comparativo entre as técnicas de diluição em caldo e diluição em ágar, nos antibiogramas para Candida. Rev. Inst. Med. trop. S. Paulo, 34: 259-262, 1992.

4. ANDRADE, Z.A. - Criptococose pulmonar localizada. Arq. bras. Med., 47: 367-370, 1997.

5. BARONI, F.A. - Ocorrência de Cryptococcus neoformans em excretas de pombos localizadas em torres de igrejas na cidade do Rio de Janeiro: fatores de virulência e sensibilidade aos antifúngicos. São Paulo, 2001. (Tese de Doutorado - Instituto de Ciências Biomédicas da Universidade de São Paulo).

6. BARRETO DE OLIVEIRA, M.T. - Sorotipos, biótipos killer, diversidade genética e mating-type de cepas de Cryptococcus neoformans isoladas de pacientes e meio ambiente no Brasil. São Paulo, 2001. (Tese de Doutorado - Instituto de Ciências Biomédicas da Universidade de São Paulo).

7. BEZERRA, C.C.F.; WANKE, B.; CAVALCANTI, M.A.S. et al. - Cryptococcus neoformans var. neoformans e var. gattii isolados de Eucalyptus camaldulensis no Brasil. In: CONGRESSO BRASILEIRO DE MICOLOGIA, Rio de Janeiro, 1998. Abstract. p. 183. G45.

8. BOEKHOUT, T.; THEELEN, B.; DIAZ, M. et al. - Hybrid genotypes in the pathogenic yeast Cryptococcus neoformans. Microbiology, 147: 891-907, 2001.

9. BRANCHINI, M.L.M. \& PAPAIORDANOU, P.M.O. - Destaque para as infecções fúngicas em pacientes com Aids e no hospedeiro imunocomprometido no Brasil. J. bras. AIDS, 1(3): 31- 34, 2000.

10. CAIUBY, M.J.; ROZENBAUM, R.; FEIJÓ, P. et al. - Associação de criptococose e histoplasmose em pacientes portadores da síndrome da imunodeficiência adquirida. Relato de 3 casos. Arq. bras. Med., 63: 443-445, 1989.

11. CALVO, B.M.; COLOMBO, A.L.; FISCHMAN,O. et al. - Avaliação da susceptibilidade aos antifúngicos e cariotipagem eletroforética de isolados clínicos de Cryptococcus neoformans de diferentes regiões do Brasil, segundo variedades e sorotipos. Braz. J. infect. Dis., 3(suppl. 2): S22, res. TL 69, 1999.

12. CALVO, B.M.; FISCHMAN, O.; CASTELO-FILHO, A. et al. - Detección de antígeno del polisacárido capsular de Cryptcococcus neoformans en pacientes con SIDA y neurocriptococosis en São Paulo, Brasil. Rev. Inst. Med. trop. S. Paulo, 33: 485490, 1991.

13. CALVO, B.M.; FISCHMAN, O.; PIGNATARI, A.; DEL BIANCO, R. \& ZAROR, L. Variedades y serotipos de Cryptococcus neoformans en pacientes con SIDA y neurocriptococosis en São Paulo, Brasil. Rev. Inst. Med. trop. S. Paulo, 32: 480482, 1990 .

14. CALVO, B.M.; COLOMBO, A.L.; FISCHMAN, O. et al. - Antifungal susceptibilities, varieties, and electrophoresis karyotypes of clinical isolates of Cryptococcus neoformans from Brazil, Chile, and Venezuela. J. clin. Microbiol., 39: 2348-2350, 2001. 
15. CAMPANA, D.R.; SAMPAIO, A.A.L.; CUNDARI, M.A.; PRADO, M.V.F.A. \& GALUPPO, M.T.G. - Criptococose-comprometimento laríngeo. Apresentação de um caso. Rev. bras. Otorrinolaring., 53: 56-59, 1987.

16. CAMPOS, E.P.; CARVALHO,V.O.; MARINHO, S.F. et al. - Estudo retrospectivo terapêutico da neurocriptococose em 112 pacientes aidéticos ou não. Rev. Soc. bras. Med. trop., 25: 241-246, 1992.

17. CAPONE, D.; GONÇALVES, A.J.R.; ANDRADE, E.M. et al. - Criptococose pulmonar por Cryptococcus não-capsulado. J. bras. Med., 50: 67-70, 1986.

18. CAVALCANTI, M.A.S. - Criptococose e seu agente etiológico no meio norte, estados do Piauí e Maranhão, Brasil. Rio de Janeiro, 1997. (Tese de Doutoramento Universidade Federal do Rio de Janeiro).

19. COLOMBO, A.L. - Avaliação in vitro por três diferentes métodos da sensibilidade de leveduras a antifúngicos azólicos. São Paulo, 1994. (Tese de Doutoramento - Escola Paulista de Medicina da Universidade Federal de São Paulo).

20. COLOMBO, A.L. - Testes de sensibilidade a antifúngicos: qual é a sua importância? Âmb. Hosp., 10: 19-25, 1995.

21. CORRÊA, M.P.S.C.; OLIVEIRA, E.C.; DUARTE, R.R.B.S. et al. - Criptococose em crianças no estado do Pará, Brasil. Rev. Soc. bras. Med. trop., 32: 505-508, 1999.

22. CORREAA, M.P.S.C.; SEVERO, L.C.; OLIVEIRA, F.M. et al. - The spectrum of computerized tomography (CT) findings in central nervous system (CNS) infection due to Cryptococcus neoformans var. gattii in immunocompetent children. Rev. Inst. Med. trop. S. Paulo, 44: 283-287, 2002.

23. CÔRTES, E.E.M. - Estudo de 826 séries de hemoculturas para fungos e bactérias em pacientes portadores do vírus da imunodeficiência humana, no Hospital Universitáiro Clementino Fraga Filho, RJ. Rio de Janeiro, 1993. (Dissertação de Mestrado - Faculdade de Medicina da Universidade Federal do Rio de Janeiro).

24. DARZÉ, C.; LUCENA, R.; GOMES, I. \& MELO, A. - Características clínicas laboratoriais de 104 casos de meningoencefalite criptocócica. Rev. Soc. bras. Med. trop., 33: 21-26, 2000

25. FARIAS DA SILVA, W.; TRAVASSOS, F.; CODECEIRA Jr., A. \& REGO, J.F. Criptococose do sistema nervoso central. Considerações a respeito de 5 casos. Neurobiologia, 31: 174-185, 1968.

26. FERNANDES, O.F.L.; COSTA, T.R.; COSTA, M.R. et al. - Cryptococcus neoformans isolados de pacientes com AIDS. Rev. Soc. bras. Med. trop., 33: 75-78, 2000

27. FILIÚ, W.F.O.; WANKE, B.; AGÜENA, S.M. et al. - Cativeiro de aves como fonte de Cryptococcus neoformans na cidade de Campo Grande, Mato Grosso do Sul, Brasil. Rev. Soc. bras. Med. trop., 35: 591-595, 2002

28. FIORILLO, A.M.; LIMA, R.H.P.; MARTINEZ, R. et al. - Meningite criptocócica: aspectos clínicos, evolutivos e histopatológicos segundo a condição predisponente. Rev. Soc. bras. Med. trop., 23: 19-25, 1990.

29. FRANZOT, S.P.; HAMDAN, J.S.; CURRIE, B.P. \& CASADEVALL, A. - Molecular epidemiology of Cryptococcus neoformans in Brazil and the United States: evidence for both local genetic differences and a global clonal population structure. J. clin. Microbiol., 35: 2243-2251, 1997.

30. FRANZOT, S.P.; SALKIN, I.F. \& CASADEVALL, A. - Cryptococcus neoformans var. grubii separate varietal status for Cryptococcus neoformans serotype A isolates. J. clin. Microbiol., 37: 838-840, 1999

31. GONÇALVES, A.J.R.; LOPES, P.F.A.; PINTO, A.M.M et al. - Criptococose: estudo de 27 casos observados no Hospital dos Servidores do Estado -INAMPS- e no Hospital Estadual São Sebastião- Rio de Janeiro. J. bras. Med., 46: 43-63, 1984.

32. HORTA, J.A.; STAATS, C.C.; CASALI, A.R. et al. - Epidemiological aspects of clinical and environmental Cryptcococcus neoformans isolates in the Brazilian state Rio Grande do Sul. Med. Mycol., 40: 565-571, 2002.
33. IGREJA, R. - Estudo da sensibilidade in vitro e análise genética de amostras clínicas seriadas de Cryptococcus neoformans. Rio de Janeiro, 1999. (Tese de Doutorado Faculdade de Medicina da Universidade Federal do Rio de Janeiro).

34. IGREJA, R. - Sensibilidade in vitro de amostras clínicas de Cryptococcus neoformans isoladas de pacientes do Rio de Janeiro. Rio de Janeiro, 1993. (Dissertação de Mestrado - Faculdade de Medicina da Universidade Federal do Rio de Janeiro).

35. KRITSKI, A.L.; RIOS-GONÇALVES, A.; ROZENBAUM, R. et al. - Criptococose do sistema nervoso central. Relato de seis casos e revisão da literatura. Rev. bras. Neurol, 22: 171-178, 1986.

36. LACAZ, C.S.; HEINS-VACCARI, E.M.; HERNÁNDEZ-ARRIAGADA, G.L. et al. Primary cutaneous Cryptococcus neoformans var. gattii serotype B, in an immunocompetent patient. Rev. Inst. Med. trop. S. Paulo, 44: 225-228, 2002.

37. LACAZ, C.S.; HEINS-VACCARI, E.M.; MELO, N.T. et al. - Neurocriptococose por Cryptococcus neoformans não-capsulado. Arq. Neuropsiquiat., 51: 395-398, 1993.

38. LACAZ, C.S.; PORTO, E.; HEINS-VACCARI, E.M. \& MELO, N.T. - Guia para identificação de fungos, actinomicetos e algas de interesse médico. São Paulo, Sarvier, 1998

39. LACAZ, C.S.; PORTO, E.; MARTINS, J.E.C.; HEINS-VACCARI, E.M. \& MELO, N.T. - Tratado de Micologia médica. 9. ed. São Paulo, Sarvier, 2002.

40. LACAZ, C.S. \& RODRIGUES, M.C. - Sorotipagem do Cryptococcus neoformans. Rev. bras. Med., 40: 297-300, 1983

41. LACAZ, C.S. \& MELHEM, M.S.C. - Ensaio imuno-alérgico com criptococcina em recrutas de um batalhão policial de São Paulo (Brasil). Rev. Hosp. Clin. Fac. Med. S. Paulo, 33: 49-51, 1978.

42. LACERDA, P.R.G.S. - Criptococose pulmonar. Bol. Cent. Estud. Hosp. Serv. Estado, 19: $43-84,1967$

43. LAZERA, M.S.; CAVALCANTI, M.A.S.; TRILLES, L.; NISHIKAWA, M.M. \& WANKE, B. - Cryptococcus neoformans var. gattii: evidence for a natural habitat related to decaying wood in pottery tree hollow. Med. Mycol., 36: 119-122, 1998.

44. LAZERA, M.S.; PIRES, F.D.A.; CAMILLO-COURA, L. et al. - Natural habitat of Cryptococcus neoformans var. gattii in decaying wood forming hollows in living trees. J. med. vet. Mycol., 34: 127-131, 1996.

45. LAZERA, M.S.; SALMITO, C.M.A.; LONDERO, A.T. et al - Possible primary ecological niche of Cryptococcus neoformans. Med. Mycol., 38: 379-383, 2000.

46. LAZERA, M.S.; WANKE, B. \& NISHIKAWA, M.M. - Isolation of both varieties of Cryptococcus neoformans from saprophytic sources in the city of Rio de Janeiro, Brazil. J. med. vet. Mycol., 31: 449-454, 1993.

47. MACHADO, C.C.; AMARAL, A.A. \& SEVERO, L.C. - Cryptococcus neoformans var neoformans isolado do solo. Rev. Inst. Med. trop. S. Paulo, 35: 77-79, 1993.

48. MELHEM, M.S.C. \& LACAZ, C.S. - Inquérito imunoalérgico com criptococina. Rev. Inst. Med. trop. S. Paulo, 18: 349-356, 1976.

49. MELO, N.T.; LACAZ, C.S.; CHARBEL, C.E. et al. - Quimiotipagem de Cryptococcus neoformans. Revisão da literatura. Novos dados epidemiológicos sobre a criptococose. Nossa experiência com o emprego do meio de CGB no estudo daquela levedura. Rev. Inst. Med. trop. S. Paulo, 35: 469-478, 1993.

50. MELO, N.T.; NIGRO, R.C.; PEREIRA, A.D.; HUGGINS, D.W. \& LACAZ, C.S. Isolamento de Cryptococcus neoformans de fezes de pombos, do solo e ninhos de pombos. Rev. bras. Med., 44: 6-9, 1987.

51. MENDES, C.M.F.; FRANCISCO, W.; SIQUEIRA, L.F.G. \& SILVEIRA, M.J. Sorotipagem de Cryptococcus neoformans. Nota epidemiológica. Rev. Microbiol. (S. Paulo), 20: 333-336, 1989. 
52. MEYER, W.; CASTAÑEDA, A., JACKSON, S. et al. - Molecular typing of Iberoamerican Cryptococcus neoformans isolates. Emerg. infect. Dis., 9: 189-195, 2003.

53. MICHALANY, J.; MATTOS, A.L.A.; MICHALANY, N.S.; FILIE, A.C. \& MONTEZZO, L.C. - Acquired immune deficiency syndrome (AIDS) in Brazil. Ann. Path., 7: 1524, 1987.

54. MINISTÉRIO DA SAÚDE DO BRASIL - Dados e pesquisa em DST e AIDS. Coordenação do programa nacional de DTS/AIDS. Brasília, 2002. (site: www.aids.gov.br).

55. MONTENEGRO, H. \& PAULA, C.R. - Environmental isolation of Cryptococcus neoformans var. gattii and C. neoformans var. neoformans in the city of São Paulo, Brazil. Med. Mycol., 38: 385-390, 2000.

56. NATIONAL COMMITTEE FOR CLINICAL LABORATORY STANDARDS (NCCLS) - Reference method for broth dilution antifungal susceptibility testing of yeasts: approved standard. Document M 27-A2. Villanova, PA, 2002. v. 17, n. 9.

57. NERY, A.S.; MELHEM, M.S.C. \& GOMES, A.M.L. - Manutenção da levedura Cryptococcus por congelamento. LAES-HAES (S.Paulo), 1(129): 194-198, 2001.

58. NISHIKAWA, M.M.; LAZERA, M.S.; BARBOSA, G.G. et al. - Serotyping of 467 Cryptococcus neoformans isolates from clinical and environmental sources in Brazil: analysis of host and regional patterns. J. clin. Microbiol., 41: 73-77, 2003.

59. NISHIKAWA, M.M.; SANT'ANNA, O.D.; LAZERA, M.S. \& WANKE, B. - Use of Dproline assimilation and CGB medium for screening Brazilian Cryptococcus neofomans isolates. J. med. vet. Mycol., 34: 365-366, 1996.

60. NÓBREGA, J.P.; LIVRAMENTO, J.A.; MACHADO, 1.R. \& SPINA-FRANÇA, A. Criptococose do sistema nervoso central: avaliação da terapêutica por anfotericina B, 5-fluorcitosina e miconazole em 18 casos. Arq. Neuro-psiquiat. (S. Paulo), 37: $28-33,1979$

61. NÓBREGA, J.P.S. - Contribuição para o estudo do emprego da anfotericina B no tratamento da neurocriptococose em pacientes submetidos a transplante renal. São Paulo, 1987. (Tese de Doutoramento - Faculdade de Medicina da Universidade de São Paulo).

62. OHKUSU, M.; TANGONAN, N.; TAKEO, K. et al. - Serotype, mating type and ploydy of Cryptococcus neoformans strains isolated from patients in Brazil. Rev. Inst. Med. trop. S. Paulo, 44: 299-302, 2002.

63. OLIVEIRA, O.V.; NEGREIROS, D.P. \& TREVISOL-BITTENCOURT, P.C. Neurocriptococose em pacientes com Aids no Hospital Nereu Ramos, FlorianópolisSC. J. bras. AIDS, 1(4): 28-34, 2000.

64. OLIVEIRA-NETTO, I.C.; MACHADO, C.C.; WAGNER, M.B. \& SEVERO, L.C. - Meio século de criptococose no Brasil: revisão de 308 casos (1941-1992). Amb. Hosp., 7: $5-16,1993$

65. PAPPALARDO, M.C.S.M. - Criptococose em Aids: estudo clínico e microbiológico em 35 pacientes acompanhados no Instituto de Infectologia Emílio Ribas, São Paulo, entre 1995 a 1997. São Paulo, 2002. (Dissertação de Mestrado - Coordenação dos Institutos de Pesquisa da Secretaria da Saude de São Paulo).

66. PASSONI, L.F.C.; WANKE, B.; NISHIKAWA, M.M. \& LAZERA, M.S. - Cryptococcus neoformans isolated from human dwellings in Rio de Janeiro, Brazil: an analysis of the domestic environment of AIDS patients with and without cryptococcosis. Med. Mycol., 36: 305-311, 1998.

67. PASSONI, L.F.C. - Wood, animals and human beings as reservoirs for human Cryptococcus neoformans infection. Rev. iberoamer. Micol., 16: 77-81, 1999.

68. PASSOS, X.S.; SANTOS, S.C.; FERRI, P.H. et al. - Atividade antifúngica de Caryocar brasiliensis (Caryocaraceae) sobre Cryptococcus neoformans. Rev. Soc. bras. Med. trop., 35: 623-627, 2002
69. PAULA, C.R.; ITO, C.H.; PURCHIO, A. et al. - Biochemical serotyping and other physiological characteristics of 40 Cryptococcus neoformans samples isolated from clinical materials in Brazil. Rev. iberoamer. Micol., 5: 105, 1988. (Abstract. p-219).

70. PAULA, C.R.; PURCHIO, A.; CORREA, B.; GAMBALE, W. \& LANFER, U.M. - A new medium for presumptive identification of Cryptococcus neoformans. Rev. Microbiol. (S. Paulo), 23: 51-53, 1992.

71. PEREIRA, S.A.L.; RODRIGUES, D.B.R.; CORREIA, D.; REIS, M.A. \& TEIXEIRA, V.P.A. - Identificação de agentes infecciosos pulmonares em autópsias de pacientes com a síndrome da imunodeficiência adquirida. Rev. Soc. bras. Med. trop., 35: $635-639,2002$

72. REIS-FILHO, J.B.; MATAS, S.L.A.; FISCHMAN, O.; MORALES, B.C. \& JULIANO, Y. - Estudo comparativo do LCR de pacientes com neurocriptococose sem AIDS e com AIDS. Rev. Inst. Med. trop. S. Paulo, 36: 225-230, 1994

73. REIS-FILHO, J.B.; NEVES, A.C.; ZYMBERG, S.T. \& OLIVEIRA, R.M.C. - O líquido cefalorraquiano inicial nas meningoencefalites por Cryptococcus neoformans. Rev. Inst. Med. trop. S. Paulo, 27: 173-178, 1985.

74. REZENDE, C. - Aspectos fenotípicos e moleculares de amostras de Cryptcococcus neoformans da região de Araraquara e Ribeirão Preto, relacionados aos perfis de suscetibilidade. Araraquara, 2002. (Dissertação de Mestrado - Instituto de Química/ UNESP).

75. REZENDE, D.G. - Isolamento de Cryptococcus neoformans de fezes de pombos e canários no Município de Alfenas. Alfenas, 2002. (Dissertação de Mestrado - Centro Universitário Federal de Alfenas).

76. RODRIGUEZ-TUDELA, J.L.; MARTÍN-DÍEZ, F.; CUENCA-ESTRELLA, M. et al. Influence of shaking on antifungal susceptibility testing of Cryptococcus neoformans: a comparison of the NCCLS standard M27A medium, buffered yeast nitrogen base, and RPMI-2\% glucose. Antimicrob. Agents Chemother., 44: 400-404, 2000.

77. ROZENBAUM, R. \& GONÇALVES, A.J. - Clinical epidemiological study of 171 cases of cryptococcosis. Clin. infect. Dis., 18: 369-380, 1994.

78. ROZENBAUM, R.; GONÇALVES, A.J.R.; WANKE, B. et al. - Cryptococcus neoformans varieties as agents of cryptococcosis in Brazil. Mycopathologia (Den Haag), 119: 133-136, 1992

79. ROZENBAUM, R.; GONÇALVES, A.J.R.; WANKE, B. \& VIEIRA, W. - Cryptococcus neoformans var. gattii in a Brazilian AIDS patient. Mycopathologia (Den Haag), 112: 33-34, 1999.

80. SAAG, M.S.; GRAYBILL, R.J.; LARSEN, R.A. et al. - Practice guidelines for the management of cryptococcal disease. Infectious Diseases Society of America. Clin. infect. Dis., 30: 710-718, 2000.

81. SEVERO, L.C.; HORM, C.L. \& WOLFFENBUTTEL, I. - Criptococose: tratamento, prognóstico e prevenção. Arq. bras. Med., 66: 455-457, 1992.

82. SEVERO, L.C.; LONDERO, A.T.; MARTINS, S.C.; REOLON, M. \& GEYER, R.G. Provável criptococose pulmonar causada por Cryptococcus neoformans nãocapsulado. Rev. Inst. Med. trop. S. Paulo, 23: 283-286, 1981.

83. SEVERO, L.C.; MATTOS-OLIVEIRA, F. \& LONDERO, T. - Cryptococcosis due to Cryptococcus neoformans var. gattii in Brazilian patients with Aids. Report of three cases. Rev. iberoamer. Micol., 16: 152-154, 1999.

84. SEVERO, L.C.; PINTO, J.A.F.; GEYER, G.R. \& YMAY, I. - Criptococose. Apresentação de um caso com nódulo pulmonar único. Rev. bras. Pat clín., 19: 164-166, 1983.

85. SEVERO, L.C.; ZARDO, I.B. \& LONDERO, A.T. - Cutaneous cryptococcosis due to Cryptococcus neoformans var. gattii. Rev. iberoamer. Micol., 18: 200-201, 2001.

86. SEVERO, L.C. - Criptococose: duas doenças? Porto Alegre, 1993. (Tese de Livre Docência - Faculdade Federal de Ciências Médicas de Porto Alegre). 
87. SEVERO, L.C. - Criptococose: atualização. Âmb. Hosp., 7: 21-39, 1994

88. SILVA, E.G. - Características fenotípicas e sensibilidade a antifúngicos de cepas de Cryptococcus neoformans var. neoformans após a inoculação em camundongos BALB/c: comparação com os resultados antes da inoculação. São Paulo, 2002. (Dissertação de Mestrado - Instituto de Ciências Biomédicas da Universidade de São Paulo).

89. SILVA, M.E. \& PAULA, L.A. - Isolamento de C. neoformans de excrementos e ninhos de pombos (Columba livia) em Salvador, Bahia. Rev. Inst. Med. trop. S. Paulo, 5: 9-11, 1963.

90. SILVA, M.E. - Ocorrência de Cryptococcus neoformans e Microsporum gypseum em solos da Bahia. Bol. Fund. G. Moniz, 17: 1-14, 1960

91. SILVA, M.L.; MELHEM, M.S.C.; OROZCO, S.F.B.; NINOMIYA, A. \& PALHARES, M.C.A. - Fungemia in patients with AIDS: etiological aspects. In: INTERNATIONAL CONFERENCE ON AIDS, 11., Vancouver, 1996. Abstracts. p. 93.

92. SIQUEIRA, R.M.T.; MONTESSI, J.; GONÇALVES, A.J.R. et al. - Criptococose disseminada: lesão pulmonar pseudotumoral, meningoencefalite, lesões cutâneas e ósseas. Relato de um caso. Arq. bras. Med., 59: 173-176, 1985.

93. SPINA-FRANÇA, A.; LIVRAMENTO, J.A.; MACHADO, L.R.; BACHESCHI, L.A. \& NÓBREGA, J.P.S. - Líquido cefalorraquidiano na Síndrome da Imunodeficiência Adquirida. Arq. Neuro-psiquiat. (S. Paulo), 45: 412-418, 1987.
94. SPINA-FRANÇA, A. \& SILVA, J.B. - Diagnóstico e tratamento da criptococose do sistema nervoso central. Considerações sobre 16 casos. Arq. Neuro-psiquiat. (S. Paulo), 26: 115-126, 1968.

95. TARASCONI, J.C.; MEDEIROS, B.S. \& XAVIER, R.G. - Criptococose pulmonar Revisão brasileira (1941-1976). J. Pneumol., 4: 54-56, 1978.

96. VIDOTTO, V.; MELHEM, M.S.C.; PUKINSKAS, S.R.B.S. et al. - Extracellular enzymatic activities in Cryptococcus neoformans AIDS Brazilian strains. Rev. iberoamer. Micol., 17: S148, 2000.

97. VIVALDINI, S.M. - Tipagem molecular de isolados sequenciais de Cryptococcus neoformans de pacientes da região de São José do Rio Preto e correlação com sensibilidade a drogas antifúngicas. Araraquara, 2003. (Dissertação de Mestrado Universidade Estadual Paulista).

98. ZANINI, M.; MARTINS, E.L.; LACAZ, C.S. et al. - Úlcera como primeira manifestação de criptococose sistêmica em paciente aidético. Med. cutan. ibero lat. Amer., 30: 22-26, 2002.

99. ZUGER, A.; LOUIE, E.; HOLZMAN, R.S.; SIMBERKOFF, M.S. \& RAHAL, J.J. Cryptococcal disease in patients with the acquired immunodeficiency syndrome: diagnostic features and outcome of treatment. Ann. intern. Med., 104: 234-240, 1986.

Received: 18 June 2003

Accepted: 23 October 2003 